\title{
Identification of heparan sulphate binding surface proteins of Helicobacter pylori: inhibition of heparan sulphate binding with sulphated carbohydrate polymers
}

\author{
M. UTT* $†$ and T. WADSTRÖM* \\ * University of Lund, Institute of Medical Microbiology, Sölvegatan 23, S-223 62 Lund, Sweden and †Bional \\ Ltd, Riia 185, EE2400 Tartu, Estonia
}

\begin{abstract}
Heparan sulphate binding to cells of the gastric pathogen Helicobacter pylori at pH 4-6 is common. Binding was inhibited by various unlabelled sulphated polysaccharides and at high ionic strength and $\mathrm{pH}$, but not by carboxylated or non-sulphated compounds. The inhibition by various sulphated compounds such as dextran sulphate and carrageenans was related to the sulphate content and not to the carbohydrate polymer backbone. The IC50 values for heparin and dextran sulphate for $H$. pylori strain 25 were calculated as $3.55 \times 10^{-7} \mathrm{M}$ and $5.01 \times 10^{-6} \mathrm{M}$ respectively. Heparin-binding proteins of $H$. pylori are exposed on the cell surface, as shown by biotinylation of cell-surface proteins before separation of outer membranes and by an indirect immunofluorescence assay. The strongest biotin-heparin binding by $H$. pylori was observed with a polypeptide in the 55-60 $\mathrm{kDa}$ region.
\end{abstract}

\section{Introduction}

Heparan sulphate and other sulphated glycosaminoglycans (GAGs) are exposed on eukaryotic cell surfaces and extracellular matrix (ECM) [1]. Several pathogenic micro-organisms and viruses - such as Bordetella pertussis, Streptococcus mutans, Leishmania donovani, Trypanosoma cruzi, Plasmodium circumsporozoites, Chlamydia trachomatis, human immunodeficiency virus, herpes virus and cytomegalovirus - interact with host cells by binding to sulphated GAG-molecules on cell surfaces and ECM [2-15]. Heparin and heparan sulphate binding to Staphylococcus aureus and Streptococci of groups A, C, and G with moderate affinity $\left(\mathrm{K}_{\mathrm{d}}=10^{-5}-10^{-7} \mathrm{M}\right)[16]$ and to Helicobacter pylori with high affinity $\left(\mathrm{K}_{\mathrm{d}}=10^{-9}-10^{-10} \mathrm{M}\right)$ [17], equivalent to the high affinity reported for heparin binding to C. trachomatis [18], has been reported previously.

Moreover, binding of ${ }^{125} \mathrm{I}$-labelled heparan sulphate to $H$. pylori was shown to be $\mathrm{pH}$ and salt dependent [17]. A recent report demonstrated that $H$. pylori

Received 27 Oct. 1995; revised version accepted 18 March 1996.

Corresponding author: Professor T. Wadström.

Publication was delayed from Oct. 1996 at the request of the authors. heparin-binding proteins (HepBP) are located on the outer-membrane surface of the cells [19].

Materials and methods

Chemicals

Bovine lung heparan sulphate (HS-3, medium content of sulphate groups) was a generous gift from L.-̊. Fransson (Department of Medical Chemistry, Lund University).

Heparin (porcine intestinal mucosa, mol. wt $6000-$ 8000 ) was purchased from Fluka (Heidelberg, Germany); dextran sulphate (mol. wt $5000=$ DS 5000, mol. wt $8000=$ DS 8000 and mol. wt $500000=$ DS 500000 ), chondroitin sulphate $\mathrm{A}, \mathrm{B}$ and $\mathrm{C}$, (Ch.SO4 A, Ch.SO4 B and Ch.SO4 C, respectively), fucoidan, carrageenan- $\lambda$ from Gigantia aciculaire and $G$. pistillata, hyaluronic acid from bovine trachea, pentosan polysulphate (PP-SO4), N-acetylneuraminic acid type VIII from sheep submaxillary glands, 2-desoxyglucosamine-2-sulphate, $\mathrm{N}$-acetylglucosamine-6-sulphate, and $\mathrm{N}$-acetylgalactosamine-6-sulphate were purchased from Sigma; bovine submaxillary gland mucin was purchased from Worthington (Freehold, NJ, USA), and dextran (mol. wt 250000 ) from Pharmacia (Uppsala, Sweden). Dextran sulphate mol. wt 5000 (DS 5000), dextran sulphate mol. wt 500000 (DS 
500,000 ), and long-arm biotin hydrazide and aminocarbazole were purchased from Sigma; basic fibroblast growth factor (bFGF) and epidermal growth factor (EGF) were purchased from Boehringer Mannheim (Mannheim, Germany). Blocking (SAT-1) and washing buffer were obtained from M. Rucheton, Orston Laboratoire, Montpelier, France. All chemicals were of analytical grade and Millipore grade de-ionised water was used in all experiments.

\section{Strains and culture conditions}

Seven strains of Helicobacter pylori $(25,1139,17874$, $17875,915,66$ and 33) from the University of Lund collection were studied.

All strains were grown in micro-aerophilic conditions at $37^{\circ} \mathrm{C}$ for 3 days on GAB-CAMP agar with defibrinated horse blood $5 \% \mathrm{v} / \mathrm{v}$ [20]. The bacteria were harvested in $0.01 \mathrm{M}$ sodium phosphate buffer, $\mathrm{pH} 7.2$, containing $0.15 \mathrm{M} \mathrm{NaCl}$ (PBS), washed once with PBS and suspended in PBS, pH 7.2 or 4.5 , to a final density of $10^{10} \mathrm{cfu} / \mathrm{ml}$. Cells were pretreated with water, $1 \mathrm{M} \mathrm{LiCl}$ and $0.2 \mathrm{M}$ acid glycine, $\mathrm{pH} 2.2$, at room temperature for $1 \mathrm{~h}$. Cells were harvested by centrifugation at $3000 \mathrm{~g}$ for 15 min and suspended in PBS, pH 7.2 or 4.5 , to a final cell density of $10^{10} \mathrm{cfu} / \mathrm{ml}$.

\section{Binding assay}

Heparan sulphate (HS-3) was derivatised at the $\alpha$ amino group of the residual serine with $p$-hydroxyphenyl propionate and labelled with ${ }^{125} \mathrm{I}$ as described by Fransson et al. [21]. The binding of ${ }^{125}$ I-labelled HS-3 to $H$. pylori was quantified as described previously [16]. Briefly, samples of ${ }^{125}$ I-labelled HS-3 (c. $25000 \mathrm{cpm})$ were added to cell suspensions $\left(10^{9} \mathrm{cfu}\right.$ in $200 \mu \mathrm{l}$ ) in a selected binding buffer (i.e., buffers with different $\mathrm{pH}$ value or different salt content) supplemented with bovine serum albumin $0.1 \%$ and $0.15 \mathrm{M} \mathrm{NaCl}$ and kept at $20^{\circ} \mathrm{C}$ for $1 \mathrm{~h}$. To each cell suspension, $2 \mathrm{ml}$ of a binding buffer (PBS, pH 7.2 or 4.5 , presence or absence of $\mathrm{NaCl}$ ) containing Tween 20 $0.05 \%$ was added. The tubes were centrifuged $(2000 \mathrm{~g}$ $10 \mathrm{~min}$ ), supernates were aspirated and bound radioactivity was determined in a gamma-counter (CliniGamma, LKB-Pharmacia, Uppsala, Sweden). All experiments were performed in duplicate and the mean value of the bound HS-3 was calculated by dividing bound radioactivity by total added radioactivity and correcting for any background radioactivity.

\section{Binding inhibition assay}

H. pylori cells $\left(10^{9} \mathrm{cfu}\right)$ in $100 \mu \mathrm{l}$ of binding buffer were mixed with $100 \mu \mathrm{l}$ of buffer solution containing $250-2.5 \mu \mathrm{g}$ putative inhibitor and kept at $20^{\circ} \mathrm{C}$ for $1 \mathrm{~h}$. ${ }^{125}$ I-labelled HS-3 was added to each tube and incubated at $20^{\circ} \mathrm{C}$ for $1 \mathrm{~h}$. These solutions were centrifuged after washing with incubation buffer and the residual cell-bound radioactivity in the pellets was determined in the gamma counter.

\section{Preparation of outer membranes}

H. pylori outer membranes were prepared as described by Doig and Trust [22]. Briefly, cells were washed with PBS and suspended in PBS containing $1 \mathrm{mM}$ phenylmethylsulphonyl fluoride (PMSF) as protease inhibitor. Cells were disrupted by sonication $(10 \times 30 \mathrm{~s}$ at $30 \mathrm{~W}$ on ice). Whole cells and cell debris were removed by centrifugation $(5000 \mathrm{~g}, 15 \mathrm{~min})$. Membranes (as cell envelopes) were collected by centrifugation $(40000 \mathrm{~g}$, $1 \mathrm{~h})$ at $4^{\circ} \mathrm{C}$. Pellets were collected and treated with sodium lauroylsarcosine $2 \%$ for $30 \mathrm{~min}$ at room temperature to remove inner membranes. An outermembrane $(\mathrm{OM})$ preparation was collected by centrifugation $\left(40000 \mathrm{~g}, 1 \mathrm{~h}, 4^{\circ} \mathrm{C}\right)$ and suspended in water for SDS-PAGE and Western blotting.

\section{SDS-PAGE and Western blotting}

$H$. pylori $\mathrm{OM}$ proteins were separated and analysed by SDS-PAGE (12\% gel or gradient gel 5-20\%) with the buffer system of Laemmli [23]. Outer membranes, treated with lauroylsarcosine $2 \%$, were washed once with PBS and dissolved in SDS-PAGE sample buffer. After SDS-PAGE, proteins were transferred to a 0.45 $\mu \mathrm{m}$ nitrocellulose membrane (Schleicher and Schuell, Dassel, Germany) or PVDF membrane (Millipore, Bedford, USA) by a semi-dry blotting technique (Ancos, Vig, Denmark). Membranes were blocked with SAT 1 for $15 \mathrm{~min}$ at room temperature, cut into 5-10$\mathrm{mm}$ strips and used in a biotin-heparin assay.

\section{Biotinylation of heparin}

Heparin ( $2 \mathrm{mg}$ ) was dissolved in $500 \mu \mathrm{l}$ of $0.1 \mathrm{M}$ sodium acetate buffer, $\mathrm{pH} 5.5$, and $5 \times 20-\mu 1$ volumes of periodate solution ( $20 \mathrm{mg}$ in $850 \mu \mathrm{l}$ of water) were added to the heparin solution at 2-min intervals. After incubation for an additional $20 \mathrm{~min}$ in the dark, excess periodate was neutralised by adding $10 \mu \mathrm{l}$ of sodium metabisulphite solution (19 mg in $100 \mu \mathrm{l}$ of water) and $20 \mu \mathrm{l}$ of long-arm biotin-hydrazide ( $1 \mathrm{mg} / \mathrm{ml}$, dissolved in dimethylsulphoxide, DMSO) was added to the heparin solution. After overnight incubation with shaking, $100 \mu \mathrm{l}$ of ethanolamine was added and incubated for $1 \mathrm{~h}$. The non-reacted biotin-hydrazide was separated on a Fast Desalt column (Pharmacia, Sweden) equilibrated with water and fractions eluting at the void volume were lyophilised. Biotin-heparin at the concentration $1 \mathrm{mg} / \mathrm{ml}$ was dissolved in water and used as a stock solution for the biotin-heparin assay.

\section{Biotin-heparin assay}

The strips of nitrocellulose were incubated in $7 \mathrm{ml}$ of binding buffer (for $\mathrm{pH}$ study buffers with different $\mathrm{pH}$; or different concentrations of salt, in the presence or 
absence of inhibitors) with $1 \mu \mathrm{g}$ of biotin-heparin ( $1 \mu \mathrm{l}$ of aqueous solution, $1 \mathrm{mg} / \mathrm{ml}$ ) for $4 \mathrm{~h}$ or overnight at room temperature with shaking. After washing four times for 7 min with binding buffer containing Tween 20 $0.05 \%$, the streptavidin-HRP conjugate (Boehringer Mannheim) at a dilution of 1 in 10000 was added and incubated for another $1 \mathrm{~h}$ at room temperature with shaking. The strips were washed as before and developed with amino carbazole $(1 \mathrm{ml})$ in $20 \mathrm{ml}$ of $50 \mathrm{mM}$ acetate buffer, $\mathrm{pH} 5.0$, containing $20 \mu \mathrm{l}$ of peroxide.

\section{Binding assay with biotin-labelled growth factors}

Binding assays with biotin-labelled bFGF and EGF were performed in PBS at $\mathrm{pH} 5.5$ and 6.5 in the presence or absence of heparin, respectively. The strips were incubated with $50 \mathrm{ng}$ of growth factors. All other conditions were the same as in the biotin-heparin assay.

\section{Results}

Binding of HS-3 to $H$. pylori cells of seven of the strains at neutral $\mathrm{pH}$ was very low. Only cells of strains 25 and 1139 bound HS-3 to a level above the background at neutral pH. However, HS-3 binding increased dramatically at $\mathrm{pH} 4.5$ up to $60-70 \%$ of the total HS-3 for some strains (Fig. 1). The influence of water, $1 \mathrm{M} \mathrm{LiCl}$ and acid glycine, $\mathrm{pH} 2.2$, on the binding to $H$. pylori strains $915,66,17874$ of HS-3 is shown in Fig. 2. Methods commonly used for releasing loosely bound surface proteins from $H$. pylori cells (i.e., acid glycine, chaotropic $\mathrm{LiCl}$ solution and water washes), did not affect the binding of ${ }^{125}$ I-labelled HS-3; on the contrary, an increase in binding was observed at $\mathrm{pH} 4.5$.

HS-3 binding to $H$. pylori 1139 cells at pH 4.5 was strongly inhibited by various sulphated compounds at

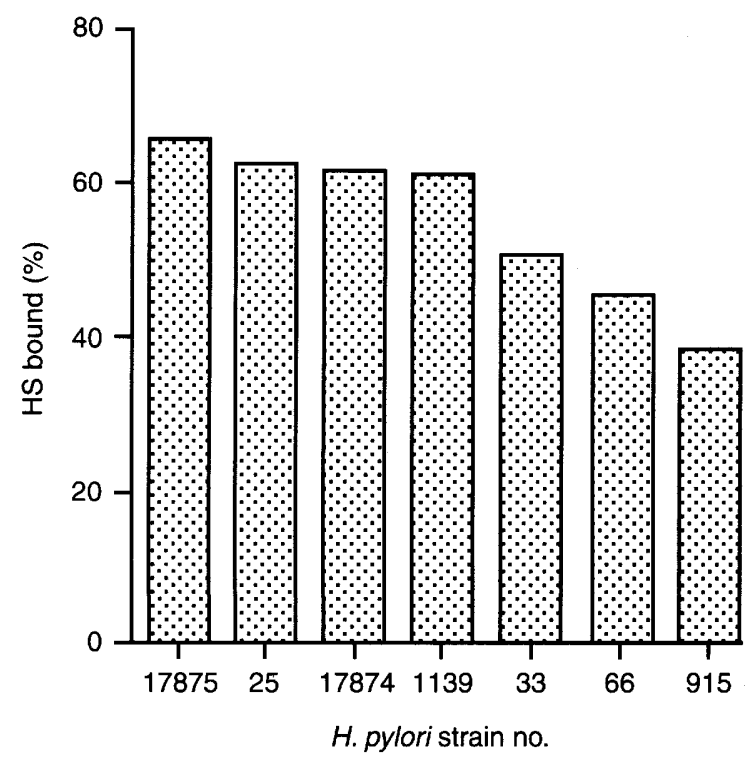

Fig. 1. Heparan sulphate (HS-3) binding to strains of $H$. pylori in PBS at $\mathrm{pH} 4.5$.

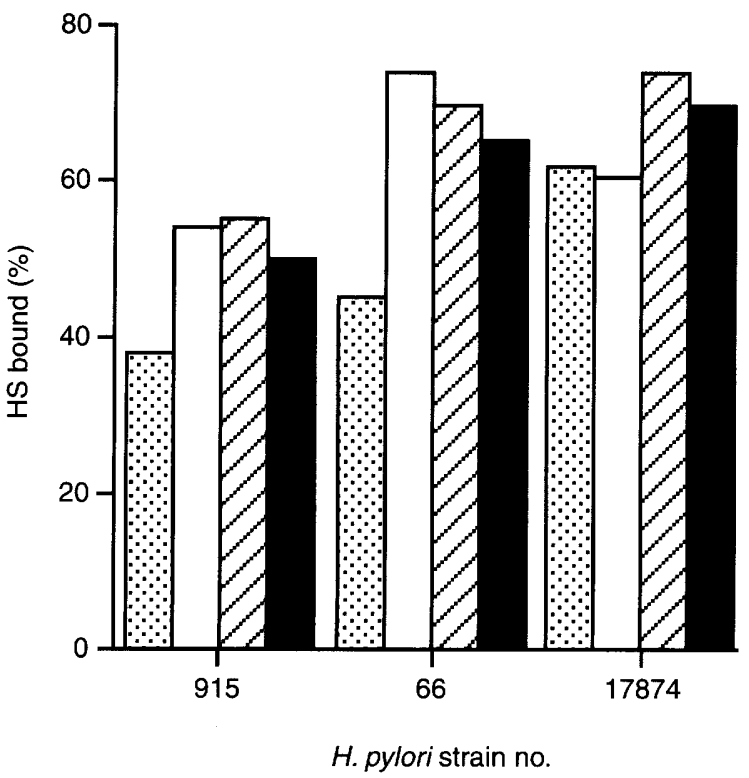

Fig. 2. Influence of different treatments on heparan sulphate (HS) binding to strains of $H$. pylori in PBS at $\mathrm{pH} 4.5$; 图, PBS, pH 7.2; $\square$, water; 2 , glycine, $\mathrm{pH} 2.2$; 口, $1 \mathrm{M} \mathrm{LiCl}$.

concentrations of $250 \mu \mathrm{g} / \mathrm{ml}$ and an increased salt concentration. To differentiate between the ability of compounds to give complete inhibition of binding, the effect of dilutions of various inhibitors was studied (Fig. 3).

More detailed analysis of the binding of ${ }^{125}$ I-labelled HS-3, heparin and DS 5000 were performed for strains 25 and 17874 (Fig. 4). From these data the IC50 values (i.e., concentration of inhibitor giving

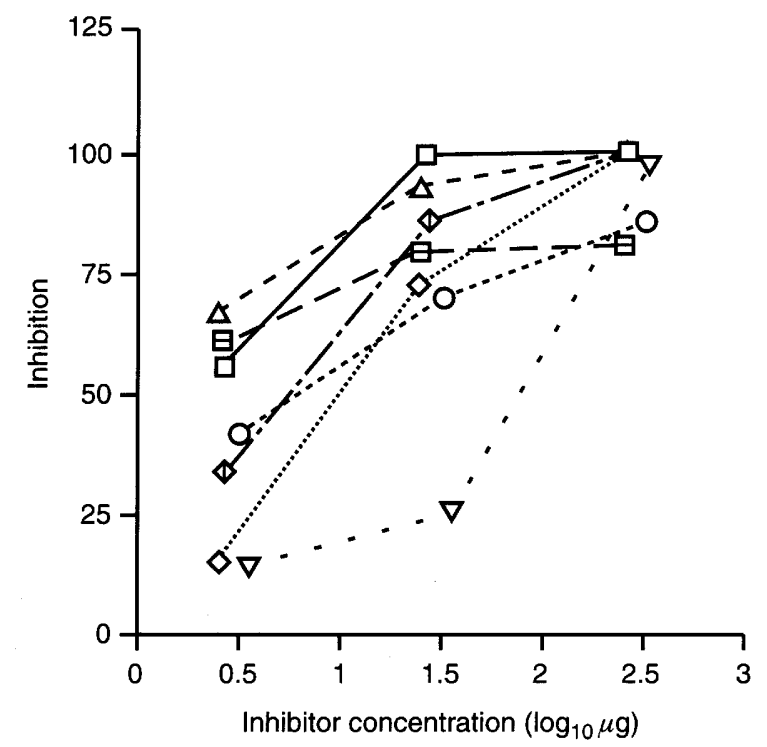

Fig. 3. Percentage inhibition of heparan sulphate binding to $H$. pylori strain 1139 in $\mathrm{PBS}$ at $\mathrm{pH} 4.5$ by various inhibitors at different concentrations. $-\square-$, heparin;

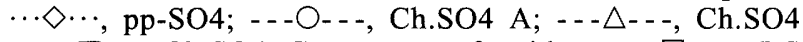
B; $\square$, Ch.SO4 C; - $-\cdot-$, fucoidan; - - $-\nabla_{--}$, DS 500000 . 


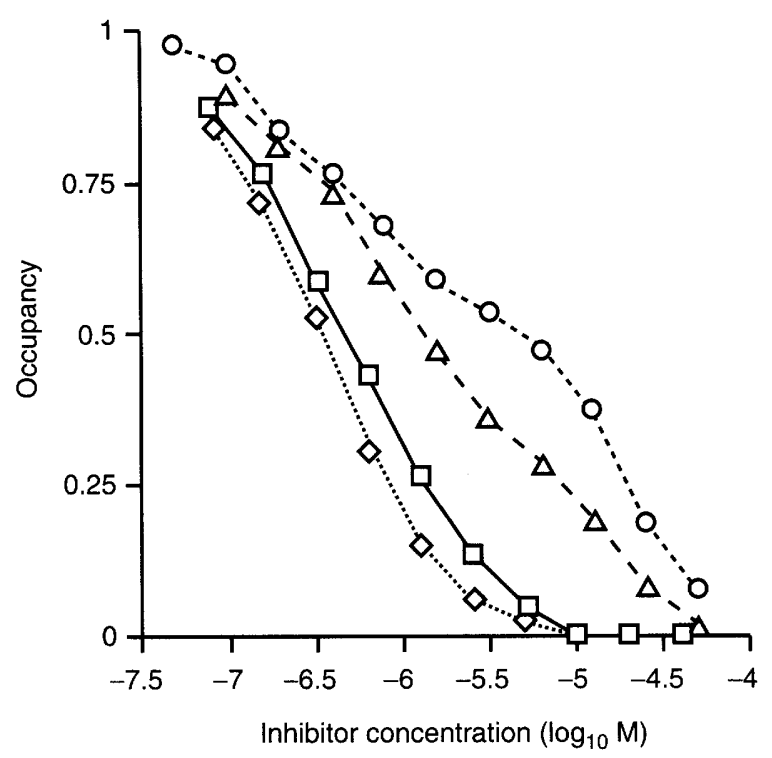

Fig. 4. Inhibition of heparan sulphate binding to cells of H. pylori strains 25 and 17874 by heparin and DS 5000 in PBS at $\mathrm{pH}$ 4.5. $-\square-$, H. pylori $17874+$ heparin; $\ldots \diamond \cdots, H$. pylori $25+$ heparin; -- -O--, H. pylori $17874+$ DS $5000 ;--\triangle--$, H. pylori $25+$ DS 5000 .

$50 \%$ inhibition) for heparin and DS 5000 were calculated for $H$. pylori strain 25 as $3.55 \times 10^{-7} \mathrm{M}$ and $1.33 \times 10^{-6} \mathrm{M}$, respectively, and for strain 17874 as $4.73 \times 10^{-7} \mathrm{M}$ and $5.01 \times 10^{-6} \mathrm{M}$, respectively. The difference in the heparin IC50 value for $H$. pylori strains 25 and 17874 was insignificant, (showing no significant difference in binding properties between these strains); the DS 5000 IC50 value for these two strains differed by five-fold.
OM proteins were separated on SDS-PAGE and analysed by Western blotting with the biotin-heparin assay; three-to-four bands in the range $15-60 \mathrm{kDa}$ were separated, confirming the location of HepBP-s on the cell surface (Fig. 5). Also, biotinylation of cell-surface proteins before separation of OM revealed the same bands as in the biotin-heparin assay (data not shown). Finally, an indirect immunofluorescence assay with a rabbit antiserum raised against a $57-\mathrm{kDa}$ polypeptide in the $55-60 \mathrm{kDa}$ region confirmed the location of this protein on the cell surface (data not shown).

When the $\mathrm{pH}$ was increased from 4.5 to 7.5 , the binding of labelled heparin decreased and, finally, only the $55-60-\mathrm{kDa}$ polypeptide gave a positive reaction at pH 6.5 and 7.2 in PBS (Fig. 5: lanes 1, 3, 5, 7 and 10). The same polypeptide reacted with biotin-bFGF at $\mathrm{pH} 5.5$ in the presence of heparin, but not in its absence (Fig. 5: lanes 14 and 12). The binding assay with biotin-EGF at $\mathrm{pH} 6.5$ did not reveal any reactive bands with or without heparin (data not shown).

\section{Discussion}

A number of studies have shown that heparin, heparan sulphate (HS) and other glycosaminoglycans (GAGs) are involved in the binding of some specific viruses and pathogenic microbes to eukaryotic cells [2-13].

HS binding to $H$. pylori cells at a $\mathrm{pH} 4-6$ seems to be a common feature (Fig. 1). In the upper gastric mucin layer, the $\mathrm{pH}$ value is $c .2-3$, which increases closer to the epithelial cell surface (about $\mathrm{pH} 7$ ).

1234567891011121314

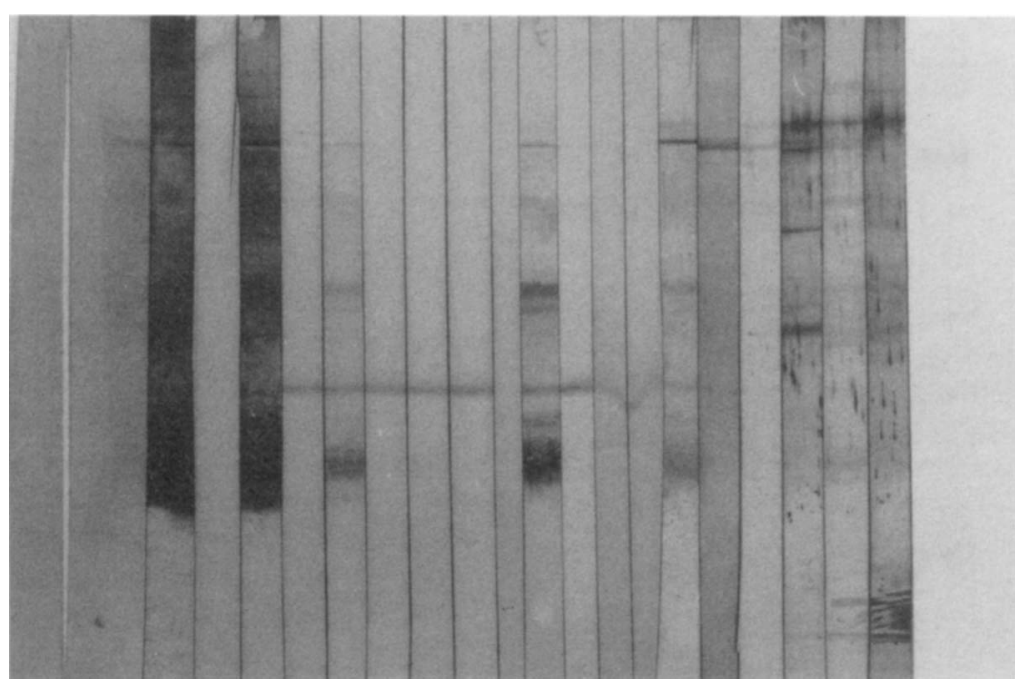

Fig. 5. Biotin-heparin assay with $H$. pylori strain 25 outer-membrane proteins separated on SDS-PAGE, transferred to nitrocellulose and probed with biotin-labelled heparin at $\mathrm{pH} 4.5-7.5$. Lane 1, $50 \mathrm{mM} \mathrm{KH}_{2} \mathrm{PO}_{4}, \mathrm{pH} 4.5 ; 3,50 \mathrm{mM}$ $\mathrm{KH}_{2} \mathrm{PO}_{4}, \mathrm{pH} 5.5 ; 5,50 \mathrm{mM} \mathrm{KH}_{2} \mathrm{PO}_{4}, \mathrm{pH} 6.5 ; 7,50 \mathrm{mM} \mathrm{KH}_{2} \mathrm{PO}_{4}, \mathrm{pH} 7.5 ; 10, \mathrm{PBS}, \mathrm{pH} 7.2 ; 12,50 \mathrm{mM} \mathrm{KH}_{2} \mathrm{PO}_{4}, \mathrm{pH} 5.5$, + bFGF; 13, $50 \mathrm{mM}^{\prime} \mathrm{KH}_{2} \mathrm{PO}_{4}, \mathrm{pH} 6.5$, + bFGF; 14, $50 \mathrm{mM} \mathrm{KH}_{2} \mathrm{PO}_{4}, \mathrm{pH} 5.5$, + heparin + bFGF; 2, 4, 6, 8, 9, 11, control with streptavidin-HRP. 
Because of high epithelial cell turnover, the mucus layer probably contains cell debris with HS and other cell-surface glycoconjugates, as well as soluble compounds to which $H$. pylori cells may bind. Interestingly, $H$. pylori OM proteins, pre-incubated with heparin, can bind heparin-dependent growth factors and interfere with peptic ulcer healing. The binding of sulphated compounds by $H$. pylori cells may have a significant role in colonisation and HS binding was shown to be inhibited by highly sulphated carbohydrate polymers (Fig. 3).

HS, dermatan sulphate and chondroitin sulphate are glycosaminoglycans on cell surfaces and in the extracellular matrix [24]. The binding of ${ }^{125}$ I-labelled HS-3 was strong at physiological salt concentrations (at $\mathrm{pH} 4.5$ ) and was almost abolished if $0.5 \mathrm{M} \mathrm{NaCl}$ was added, indicating that mainly ionic interactions are involved. Structurally different polysaccharides gave strong inhibition of ${ }^{125}$ I-labelled HS-3 binding to $H$. pylori cells, indicating that the oligosaccharide structures are not so important as the density of sulphate groups on these polymers. Interestingly, nonsulphated hyaluronic acid with a similar structure to heparin, HS and chondroitin 4- and 6-sulphates did not inhibit HS binding to cells of the seven $H$. pylori strains, whereas a structurally different heparinoid (pentosan polysulphate) gave a strong inhibition (Fig. 3). On the contrary, sulphated monosaccharide had low inhibitory activity (data not shown).

Monophasic inhibition curves for heparin are typical for non-selective competitors and the IC50 value demonstrates moderate binding affinity of heparin to the HS cell-surface proteins of $H$. pylori.

A number of tissue-invasive bacterial pathogens bind to specific cell-surface glycoproteins and glycolipids on epithelial cells. Following epithelial damage, some of these pathogens may also bind to subepithelial structures such as various extracellular matrix (ECM) molecules to promote tissue colonisation and survival.

Previously studies have shown that $H$. pylori specifically interacts with two major basal membrane ECM molecules, collagen type IV and laminin [25, 26]. The following hypothesis attempts to define the possible role of HS binding to specific surface molecules of $H$. pylori in the gastric epithelium and in subepithelial extracellular matrix. It seems likely that $H$. pylori may first interact with sialoglycoconjugates and Lewis blood group structures in the lower gastric mucin layer and on epithelial cell surfaces [27]. Binding to cell-surface GAG molecules may trigger cell interactions, as proposed for other GAG-binding pathogens such as trypanosomes and chlamydiae [28, 29].

However, GAG binding to $H$. pylori - together with binding to ECM molecules, including fibronectin, vitronectin, type IV collagen and laminin - may allow it to become coated efficiently with host molecules capable of preventing attack by professional phagocytes and a strong immune response. This may in part explain why $H$. pylori is a 'slow pathogen' $[30,31]$, allowing survival for decades in the gastric mucosa of patients with chronic type B gastritis.

In conclusion, $H$. pylori cells interact strongly with HS at a low $\mathrm{pH}$ value (4.5) and more than a surface protein are involved in this interaction. According to the biotin-heparin assay, only the protein in the 55$60 \mathrm{kDa}$ region interacts with heparin at a neutral $\mathrm{pH}$ (6-7). Although the $H$. pylori cell-surface proteins do not bind bFGF and EGF at $\mathrm{pH} 5-7$, this may occur when the 'bridge' is provided by the heparin molecule.

This work was supported by a grant from the Swedish Medical Research Council (16x-84723), a grant from Magnus Bergvall and the Medical Faculty, Lund, and a grant from the Swedish Institute to M.U. We thank L.-A. Fransson and Cheng Fang for heparan sulphate (HS-3) and P. Aleljung for useful comments and discussions.

\section{References}

1. Lindahl U, Lidholt K, Spillmann D, Kjellen L. More to "heparin" than anticoagulation. Thromb Res 1994; 75: 1-32.

2. Baba M, Pauwels R, Balzarini J, Arnout J, Desmyter J, De Clercq E. Mechanism of inhibitory effect of dextran sulfate and heparin on replication of human immunodeficiency virus in vitro. Proc Natl Acad Sci USA 1988; 85: 6132-6136.

3. Butcher BA, Sklar LA, Seamer LC, Glew RH. Heparin enhances the interaction of infective Leishmania donovani promastigotes with mouse peritoneal macrophages. A fluorescence flow cytometric analysis. $J$ Immunol 1992; 148: 2879-2886.

4. Choi SH, Stinson MW. Purification of a Streptococcus mutans protein that binds to heart tissue and glycosaminoglycans. Infect Immun 1989; 57: 3834-3840.

5. Frevert U, Sinnis P, Cerami C, Shreffler W, Takacs B, Nussenzweig V. Malaria circumsporozoite protein binds to heparan sulphate proteoglycans associated with the surface membrane of hepatocytes. J Exp Med 1993; 177: 1287-1298.

6. Kulane A, Ekre HP, Perlmann P, Rombo L, Wahlgren M, Wahlin B. Effect of different fractions of heparin on Plasmodium falciparum merozoite invasion of red blood cells in vitro. Am J Trop Med Hyg 1992; 46: 589-594.

7. Lycke E, Johansson M, Svennerholm B, Lindahl U. Binding of herpes simplex virus to cellular heparan sulphate, an initial step in the adsorption process. $J$ Gen Virol 1991; 72: $1131-1137$.

8. McClure MO, Moore JP, Blanc DF et al. Investigations into the mechanism by which sulfated polysaccharides inhibit HIV infection in vitro. AIDS Res Hum Retroviruses 1992; 8: 19-26.

9. Ortega-Barria E, Pereira MEA. Entry of Trypanozoma cruzi into eukaryotic cells. Infect Agents Dis 1992; 1: 136-145.

10. Pancake SJ, Holt GD, Mellouk S, Hoffman SL. Malaria sporozoites and circumsporozoite proteins bind specifically to sulfated glycoconjugates. J Cell Biol 1992; 117: 1351-1357.

11. Stephens RS. Molecular mimicry and Chlamydia-host cell interactions. In: Mårdh PA, La Placa $\mathrm{M}$, Ward $\mathrm{M}$ (eds) Proceedings of the European Society for Chlamydia Research. Stockholm, Sept, 1992: 6-10.

12. Trybala E, Svennerholm B, Bergström T, Olofsson S, Jeansson $\mathrm{S}$, Goodman JL. Herpes simplex virus type 1 induced hemagglutination: glycoprotein $\mathrm{C}$ mediates virus binding to erythrocyte surface heparan sulfate. $J$ Virol 1993; 67: $1278-1285$.

13. Vaudaux P, Avramoglou T, Letourneur D, Lew DP, Jozefonvicz J. Inhibition by heparin and derivatized dextrans of Staphylococcus aureus adhesion to fibronectin-coated biomaterials. J Biomater Sci Polym Ed 1992; 4: 89-97. 
14. Ljungh $\AA$, Wadström $T$. Binding of extracellular matrix proteins by microbes. Methods Enzymol 1995; 253: 501-514.

15. Wadström $T$, Ringner $M$, Valkonen $K H$. Interactions of microbial lectins and extracellular matrix. Zentralbl Bakteriol 1994; 25 Suppl: 73-87.

16. Liang OD, Ascencio F, Fransson L- $\AA$, Wadström T. Binding of heparan sulphate to Staphylococcus aureus. Infect Immun 1992; 60: $899-906$.

17. Ascencio F, Fransson L $\AA$, Wadström T. Affinity of the gastric pathogen Helicobacter pylori for the N-sulphated glycosaminoglycan heparan sulphate. $J$ Med Microbiol 1993; 38: $240-244$.

18. Stephens RS. Molecular mimicry and Chlamydia trachomatis infection of eukaryotic cells. Trends Microbiol 1994; 2: $99-101$.

19. Hirmo $S$, Utt $M$, Ringner $M$, Wadström $T$. Inhibition of heparan sulphate and other glycosaminoglycans binding to Helicobacter pylori by various polysulphated carbohydrates. FEMS Immunol Med Microbiol 1995; 10: 301-306.

20. Soltesz V, Schalen C, Mårdh PA. New selective medium for Campylobacter pylori. In: Kaijser B, Falsen E, (eds) Proceedings of the Fourth International Workshop on Campylobacter Infection. Gothenburg, Sweden, 1988: 433-436.

21. Fransson L-A, Havsmark B, Silverberg I. A method for the sequence analysis of dermatan sulphate. Biochem $J$ 1990; 269: 381-388.

22. Doig P, Trust TJ. Identification of surface-exposed outer membrane antigens of Helicobacter pylori. Infect Immun 1994; 62: 4526-4533.
23. Laemmli UK. Cleavage of structural proteins during the assembly of the head of the bacteriophage T4. Nature 1970; 227: $680-685$.

24. Fransson L- $\AA$. Structure and functions of cell associated proteoglycans: FIBS 12. Elsevier. 1987: 406-411.

25. Trust TJ, Doig P, Emödy L, Kienle Z, Wadström T, O’Toole P. High-affinity binding of the basement membrane proteins collagen type IV and laminin to the gastric pathogen Helicobacter pylori. Infect Immun 1991; 59: 4398-4404.

26. Valkonen $\mathrm{KH}$, Ringnér $\mathrm{M}$, Ljungh $\AA$, Wadström T. Highaffinity binding of laminin by Helicobacter pylori: evidence for a lectin-like interaction. FEMS Microbiol Immunol 1993; 7 $29-37$.

27. Borén T, Falk P, Roth KA, Larson G, Normark S. Attachment of Helicobacter pylori to human gastric epithelium mediated by blood group antigens. Science 1993; 262: 1892-1895.

28. Chen JC-R, Stephens RS. Trachoma and LGV biovars of Chlamydia trachomatis share the same glycosaminoglycandependent mechanism for infection of eukaryotic cells. Mol Microbiol 1994; 11: 501-507.

29. Ortega-Barria E, Pereira MEA. A novel T. cruzi heparinbinding protein promotes fibroblast adhesion and penetration of engineered bacteria and Trypanozomes into mammalian cells. Cell 1991; 67: 411-421.

30. Blaser MJ. Pathogenesis of Helicobacter pylori-induced inflammation: a "slow" bacterial infection? Eur J Gastroenterol Hepatol 1992; 4 Suppl 1: 17-19.

31. Blaser MJ. Hypothesis on the pathogenesis and natural history of Helicobacter pylori-induced inflammation. Gastroenterology 1992; 102: $720-727$. 